\title{
Effect of bleaching permeate from microfiltered skim milk on $80 \%$ serum protein concentrate ${ }^{1}$
}

\author{
Rachel E. Campbell, ${ }^{*}$ Michael C. Adams, $†$ MaryAnne Drake, ${ }^{* 2}$ and David M. Barbano† \\ ${ }^{*}$ Department of Food, Bioprocessing and Nutritional Sciences, Southeast Dairy Foods Research Center, North Carolina State University, \\ Raleigh 27695 \\ †Northeast Dairy Foods Research Center, Department of Food Science, Cornell University, Ithaca, NY 14853
}

\section{ABSTRACT}

Whey proteins that have been removed before the cheese-making process are referred to as "native" whey proteins or milk serum proteins. Because serum proteins isolated directly from milk are not exposed to the cheese-making process, they are free from functional or sensory effects arising from this process. Whey proteins used in food and beverage applications are largely derived from annatto-colored Cheddar cheese. Some of the annatto is left in the whey and this color is converted to a colorless compound by bleaching. The effect of bleaching serum proteins on flavor and functionality of spray-dried protein provides a platform to investigate the effect of bleaching free from the confounding effects of cheese manufacture. The objective of this study was to characterize and compare the sensory and functional properties of $80 \%$ milk serum protein concentrate (SPC80) produced from bleached and unbleached microfiltration (MF) permeate made from skim milk with and without added annatto color. Colored and uncolored MF permeates were bleached with benzoyl peroxide (BP) or hydrogen peroxide (HP), ultrafiltered, diafiltered, and spray-dried. The SPC80 from unbleached colored and uncolored MF permeates were manufactured as controls. All treatments were manufactured in triplicate. All SPC80 were evaluated by sensory testing, instrumental analyses, functionality, color, and proximate analysis. The HP-bleached SPC80 was higher in lipid oxidation compounds than BP-bleached or unbleached SPC80, specifically hexanal, heptanal, nonanal, decanal, and 2,3-octadienone. The HP treatments were higher in aroma intensity and cardboard and fatty flavors compared with the unbleached and

\footnotetext{
Received August 11, 2012.

Accepted November 4, 2012.

${ }^{1}$ Use of names, names of ingredients, and identification of specific models of equipment is for scientific clarity and does not constitute any endorsement of product by authors, Cornell University, North Carolina State University, the Northeast Dairy Foods Research Center, or the Southeast Dairy Foods Research Center.

${ }^{2}$ Corresponding author: maryanne_drake@ncsu.edu
}

BP-bleached SPC80. The SPC80 bleached with BP had lower concentrations of norbixin compared with SPC80 bleached with HP. Functionality testing demonstrated that HP treatments had more soluble protein after 10 min of heating at $90^{\circ} \mathrm{C}$ and $\mathrm{pH} 4.6$ and $\mathrm{pH} 7$ compared with the no bleach and BP treatments, regardless of additional color. Foams generated from bleached SPC80 were more stable than those from unbleached SPC80, and those bleached with HP were lower in yield stress than other SPC80. Overall, HP bleaching destroyed less norbixin and caused more lipid oxidation and subsequent off-flavors than did BP bleaching. However, the heat stability of SPC 80 was enhanced by HP bleaching compared with control treatments or BP bleaching.

Key words: flavor, bleaching, milk serum protein, native whey protein

\section{INTRODUCTION}

Whey proteins that have been removed before the cheese-making process are referred to as "native" whey proteins or milk serum proteins (Drake et al., 2009; Evans et al., 2009, 2010). Milk serum proteins are a valuable milk fraction and are not exposed to the cheese-making process, thus leaving them free of any functional or sensory effects from this process. It may be advantageous to remove the milk serum proteins before cheese making for several reasons; namely, to produce more mild-tasting and consistent value-added whey protein products. If milk serum proteins were removed before the manufacture of cheese, the cheese composition would be the same because most of these proteins are not retained in the cheese (Nelson and Barbano, 2005a). Nelson and Barbano (2005b) went on to demonstrate that a high quality cheese could be made from milk with low serum protein content.

Recent studies have shown that gel strength, foaming, and emulsification properties of milk serum protein powders (24 to $37 \%$ protein) were significantly stronger than whey protein powders (24 to $37 \%$ protein) made from cheese whey (50\% Gouda, $50 \%$ Emmental) and that these differences could be explained by de- 
naturation rate, fat residues, and protein composition, respectively (Heino et al., 2007). The serum protein concentrate (SPC) powders used by Heino et al. (2007) had lower fat content than the corresponding whey protein concentrate (WPC) powders. The higher fat residues present in conventional whey protein powders led to decreased foam stability and reduced foam volume compared with the SPC. Increased functionality (foaming, gelation, and emulsification) is not the only benefit to serum whey proteins versus conventionally processed whey proteins. Serum whey proteins are purported to have a higher biological activity than traditional whey proteins (Marcelo and Rizvi, 2007). Whey proteins can be used in a variety of applications, and serum whey proteins may be of particular interest to the pharmaceutical and biomedical industries because these proteins are still in their "native conformation" (Marcelo and Rizvi, 2007).

Lipid oxidation is initiated during the cheese-making process (Campbell et al., 2011b), and subsequent steps in whey processing increase volatile oxidation products (Croissant et al., 2009; Campbell et al., 2011a; Whitson et al., 2011). Serum protein concentrates are lower in fat than conventionally processed whey protein concentrates, and previous work has demonstrated that SPC are also lower in lipid oxidation compounds and lipid oxidation-associated off-flavors compared with whey proteins (Evans et al., 2010). These differences are attributed not only to decreased fat content but also to the lack of residual effects from the cheese-making process.

Traditional US Cheddar whey often contains residual annatto color (norbixin) that is added to the cheese milk to impart a desirable yellow or orange color in the cheese. Once the whey is removed, the whey is often bleached to make it more acceptable for use in a wide range of food products (Kang et al., 2010). Currently, 2 chemical bleaching agents are approved for use in the United States: benzoyl peroxide (BP) and hydrogen peroxide (HP; Kang et al., 2010). Both of these bleaching agents have a negative effect on the flavor of whey protein products (Croissant et al., 2009; Listiyani et al., 2011; Jervis et al., 2012). The effect of bleaching on serum protein flavor and functionality has not been investigated, and using SPC provides a way to compare the effects of bleaching and bleaching agent without the confounding effects of the cheese-making process. The objective of this study was to characterize and compare the sensory and functional properties of $80 \%$ milk serum protein concentrates (SPC80) produced from bleached and unbleached microfiltration (MF) permeate made from skim milk with and without added annatto color.

\section{MATERIALS AND METHODS}

\section{Experimental Design}

For SPC80 manufacture, a $3 \times 2$ full factorial design was used, with 3 levels of bleaching (no bleach, $50 \mathrm{mg} /$ $\mathrm{kg}$ of $\mathrm{BP}$, or $500 \mathrm{mg} / \mathrm{kg}$ of $\mathrm{HP}$ ) and 2 levels of coloring (no annatto or $0.066 \mathrm{~mL}$ of annatto $/ \mathrm{kg}$ of milk). The experiments were replicated 3 times, resulting in 18 MF processing runs for SPC80 manufacture. Each individual processing run was conducted over 3 consecutive days in a week.

\section{Microfiltration Processing of Skim Milk}

Premicrofiltration Processing. On the first day of processing, raw whole milk (about $1,150 \mathrm{~kg}$ ) was pasteurized using a plate heat exchanger (model 080-S, AGC Engineering, Manassas, VA) at $72^{\circ} \mathrm{C}$ for $16 \mathrm{~s}$, and then the milk was cooled to $50^{\circ} \mathrm{C}$ and separated with a centrifugal cream separator (model 619, DeLaval Inc., Kansas, MO). After separation, the skim milk (about $1,060 \mathrm{~kg}$ ) was kept at $50^{\circ} \mathrm{C}$ and processed with a UF system in batch recirculation mode using a PES SW membrane (model 3838, GEA Niro Inc., Hudson, WI) with a molecular weight cutoff of 10,000 Da. Before processing, the UF membrane was cleaned following the procedure described by Evans et al. (2009). The skim milk was ultrafiltered for about $4 \mathrm{~h}$ to achieve a concentration factor $(\mathbf{C F})$ of approximately $2.2 \times$. After UF, the retentate was diluted back to the original total protein content of the skim milk as determined by infrared spectroscopy (IR). For the treatments with added annatto, the colorant (annatto cheese color, $2 \times, \mathrm{P} / \mathrm{N}$ 70741, Chr. Hansen Inc., Milwaukee, WI) was added $(0.066 \mathrm{~mL} / \mathrm{kg}$ of milk) to the diluted UF retentate. The diluted UF retentate was then cooled using a plate heat exchanger and stored overnight at $\leq 4^{\circ} \mathrm{C}$. The UF system was then cleaned as described by Evans et al. (2009). This UF step was conducted to reduce the lactose content of the MF feed so that the MF retentate produced in this study could be used in another study. In practice, SPC80 could be produced without ultrafiltering the skim milk before MF.

Microfiltration. The next day, the diluted UF retentate was microfiltered in a continuous feed-and-bleed $3 \times$ process using a pilot-scale system. The day before processing, the MF system was cleaned as described by Zulewska et al. (2009). The MF system (Tetra Alcross M7, TetraPak Filtration Systems, Aarhus, Denmark) was equipped with ceramic Membralox graded permeability membranes (Pall Corp., Cortland, NY, nominal pore diameter of $0.1 \mu \mathrm{m}$, surface area of $\left.1.7 \mathrm{~m}^{2}\right)$. Seven 
tubular, 19-channel ceramic membranes were housed in the tubular stainless steel MF module. The MF system consisted of a feed pump (type LKH 10/110 SSS, 1.75 $\mathrm{kW}$ ) and a retentate recirculation pump (type LKH 20/125 SSS, $6.3 \mathrm{~kW}$ ), both from Alfa Laval (Kansas City, MO). The retentate recirculation pump was equipped with a variable frequency drive (MC series, model M12100C, Lenze AC Tech, Uxbridge, MA) and a magnetic flow transmitter (I/A series, IMT25, Foxboro/Invensys plc, Foxboro, MA) so that the cross-flow velocity could be controlled and monitored, respectively. More complete details of the MF processing conditions are provided by Adams et al. (accepted). After processing, the MF system was cleaned as described by Zulewska et al. (2009). If the MF permeate was not bleached, it was cooled to $4^{\circ} \mathrm{C}$ using a plate heat exchanger and held overnight at $\leq 4^{\circ} \mathrm{C}$.

\section{SPC Manufacture}

Bleaching of MF Permeate. If the MF permeate was to be bleached, it was recirculated through a plate heat exchanger in a large stainless steel tank to heat it to $66^{\circ} \mathrm{C}$. The bleaching process and conditions for MF permeate were identical to those applied to fluid whey by Jervis et al. (2012) to allow for direct comparison of results. Two different bleaches were used: $\mathrm{BP}$ at $50 \mathrm{mg} / \mathrm{kg}$ (Oxylite Type XX benzoyl peroxide $32 \%$ by weight, Nelson Jameson, Marshfield, WI) or $\mathrm{HP}$ at $500 \mathrm{mg} / \mathrm{kg}$ (35\% wt/wt hydrogen peroxide, FCC grade, Columbus Chemical Industries Inc., Columbus, WI). When bleaching with BP, the powdered bleach was mixed with about $30 \mathrm{~kg}$ of MF permeate using a high shear mixer and then added to the remainder of the MF permeate. The permeate was held for $30 \mathrm{~min}$ at $66^{\circ} \mathrm{C}$ with agitation and then cooled with a plate heat exchanger and held overnight at $4^{\circ} \mathrm{C}$. When bleaching with $\mathrm{HP}$, the liquid bleach was added to about $30 \mathrm{~kg}$ of MF permeate, mixed with the remainder of the MF permeate, and agitated for $30 \mathrm{~min}$ at $66^{\circ} \mathrm{C}$. The HP concentration in the liquid bleach was diluted from $35 \%$ to $10 \%$ (wt/wt) concentration. The $10 \%$ (wt/ wt) concentration was verified by using a $10 \%$ HP test strip (Indigo Instruments, Niagara Falls, NY). If the HP concentration was lower than $10 \%$, then the actual concentration was calculated and the amount of HP was adjusted to achieve a level of $500 \mathrm{mg} / \mathrm{kg}$ in the MF permeate. After $30 \mathrm{~min}$ at $66^{\circ} \mathrm{C}$, the MF permeate was cooled with a plate heat exchanger to $50^{\circ} \mathrm{C}$, liquid catalase enzyme derived from Aspergillus niger (FoodPro CAT, PD 216626-2.0EN, Danisco, Madison, WI) was added at $20 \mathrm{mg} / \mathrm{kg}$, and the MF permeate was mixed for $10 \mathrm{~min}$. The MF permeate was then cooled with a plate heat exchanger and held overnight at $\leq 4^{\circ} \mathrm{C}$.
Ultrafiltration of MF Permeate. The following day, approximately $530 \mathrm{~kg}$ of MF permeate was weighed into a vat, heated to $50^{\circ} \mathrm{C}$ using a plate heat exchanger, and processed with a UF system in batch recirculation mode using a PES SW UF membrane (model 3838, GEA Niro Inc.; nominal molecular weight cutoff of 10,000 Da, surface area of $13.6 \mathrm{~m}^{2}$ ). Before processing, the UF membrane was cleaned following the procedure described by Evans et al. (2009). The initial clean water flux was about $53 \mathrm{~L} / \mathrm{m}^{2} \cdot \mathrm{h}$. During processing, the system was operated in a constant pressure mode with $276 \mathrm{kPa}$ of retentate inlet pressure, $103 \mathrm{kPa}$ of retentate outlet pressure, and no backpressure on the permeate side of the membrane. The MF permeate was ultrafiltered for about 90 min. Every 15 min during processing, flux was measured and samples of permeate and retentate were taken for composition analysis using IR to monitor the process. Ultrafiltration was continued until the protein content of the retentate was $51 \%$ protein as a percentage of lactose plus fat plus protein, as determined by IR. The corresponding $\mathrm{CF}$ was about $3.8 \times$. After UF, the retentate was diluted with pasteurized reverse osmosis water at $50^{\circ} \mathrm{C}$ to bring the weight back to the original total weight of the starting MF permeate for diafiltration (DF). The membrane was not cleaned before proceeding to the DF stage. The mixture was recirculated through the membrane for $5 \mathrm{~min}$ to ensure complete mixing, and then the DF process was started. Diluted UF retentate was DF for about 120 min. Diafiltration was continued until the protein content of the retentate measured by IR was $92 \%$ protein as a percentage of lactose plus fat plus protein in the retentate. The corresponding $\mathrm{CF}$ was about $11.2 \times$. After producing the liquid SPC80, the UF system was cleaned as described by Evans et al. (2009). The fouled water flux before cleaning was, on average, $36 \%$ of the initial clean water flux (19 vs. $53 \mathrm{~L} / \mathrm{m}^{2} \cdot \mathrm{h}$ ), and the clean water flux after cleaning was similar to that before processing (about $53 \mathrm{~L} / \mathrm{m}^{2} \cdot \mathrm{h}$ ).

Spray Drying. The SPC80 were spray-dried using a spray dryer (model 1, Niro Atomizer Inc., Columbia, MD). The feed material (about $40 \mathrm{~kg}$ ) was kept at or below $7^{\circ} \mathrm{C}$. The spray dryer was equipped with an FU11 atomizer rotating at 23,000 rpm and the feed rate was $16 \mathrm{~kg} / \mathrm{h}$. The inlet temperature was $200^{\circ} \mathrm{C}$ and the outlet temperature at the bottom of the spray dryer cone was $95^{\circ} \mathrm{C}$. The powder from the first $10 \mathrm{~min}$ of the run was discarded. Powder exited the bottom of the dryer cone, went through a cyclone to separate the powder from the hot air, and was collected. The temperature of the powder in the collection vessel was about 30 to $35^{\circ} \mathrm{C}$. The dried product was collected, mixed, and packaged every $30 \mathrm{~min}$. The total time of the drying run was approximately $3.5 \mathrm{~h}$. The SPC80 for sensory 
and functional property testing was packaged in polyethylene terephthalate (Mylar) zip-lock bags (Sorbent Systems, Los Angeles, CA) and shipped to North Carolina State University (Raleigh). Upon receipt, samples were stored at $-80^{\circ} \mathrm{C}$.

\section{Chemical Analyses}

The MF permeate was analyzed for TS, fat, total nitrogen, NPN, and noncasein nitrogen content using forced-air oven drying (AOAC International, 2000; method 990.20; 33.2.44), ether extraction (AOAC International, 2000; method 989.05; 33.2.26), Kjeldahl (AOAC International, 2000; method 991.20; 33.2.11), Kjeldahl (AOAC International, 2000; method 991.21; 33.2.12), and Kjeldahl (AOAC International, 2000; method 998.05; 33.2.64) methods, respectively. Crude protein was calculated by multiplying total $\mathrm{N}$ by 6.38. The $\mathrm{pH}$ of $\mathrm{MF}$ permeate was measured with a solid polymer electrode (HA405-DXK-S8/120, MettlerToledo, Bedford, MA) and an Accumet $915 \mathrm{pH}$ meter (Fisher Scientific, Pittsburgh, PA) that was calibrated at $50^{\circ} \mathrm{C}$ using standard $\mathrm{pH} 4$ and 7 buffer solutions (Fisher Scientific).

The SPC 80 powders were reconstituted to $10 \%$ solids and the liquids were analyzed for fat and total $\mathrm{N}$ by the methods indicated above. The $\mathrm{pH}$ was measured with an electrode (Electrolyte 9823, Mettler Toledo) that was standardized at $\mathrm{pH} 7.01$ and 4.00 at $22^{\circ} \mathrm{C}$. The reconstituted samples were analyzed for TS content by forced-air oven drying (AOAC International, 2000; method 990.20; 33.2.44), and moisture content of the powder was calculated. Mineral analysis was determined by the North Carolina State University Analytical Services Laboratory (Raleigh) using a standard dry ash method with inductively coupled plasma optical emission spectroscopy (Lloyd et al., 2009).

\section{Color Analysis of Liquid and Spray-Dried SPC80}

The Hunter L (lightness), a (red-green), and b (yellow-blue) values for the fresh SPC80 powders and reconstituted liquids ( $10 \%$ solids, wt/vol) were determined in duplicate with a MacBeth Color-Eye spectrophotometer (model 2020, Kollmorgen Instruments Corp., Newburgh, NY) with Optiview software from the same company. Methods were identical to those used in Jervis et al. (2012).

\section{Norbixin Extraction and Quantification}

Norbixin extraction and quantification by UV-visible spectroscopy from SPC80 was conducted using the method from Campbell et al. (2011a) and applied by
Jervis et al. (2012). Extractions were performed under lights covered with premium full-spectrum F885 flat sheet filters (Ergomart, Dallas, TX) to minimize norbixin isomerization and degradation (Mercadante, 2008). Norbixin in SPC80 (1 g) was solvent extracted followed by column solid-phase extraction purification.

The concentration of norbixin was determined spectrophotometrically using a UV-visible spectrophotometer (UV-1700 Pharmaspec, Shimadzu, Durham, NC). A $0.7-\mathrm{mL}$ aliquot of each sample was transferred to a 1-cm 28Q10 Spectrosil quartz cuvette (Starna Cells Inc., Atascadero, CA) and measured at $458 \mathrm{~nm}$, the maxima for norbixin. A 5-point standard curve was created within the concentration range from $50 \mu \mathrm{g} / \mathrm{kg}$ to $10 \mathrm{mg} / \mathrm{kg}$ norbixin. Norbixin powder (45\% wt/wt, Chr. Hansen) was rehydrated in $2.5 \%$ potassium hydroxide solution (VWR International, Suwanee, GA) and then diluted in methanol:glacial acetic acid [7:3 ( $\mathrm{vol} / \mathrm{vol})]$. Norbixin concentration was calculated by TS with correction for dilution during the extraction and solidphase extraction processes and by an external standard curve. Measurements on the spectrophotometer were completed in duplicate.

\section{Descriptive Sensory Analysis}

Sensory analysis was conducted on rehydrated SPC80 (10\% wt/vol) using a trained descriptive sensory panel and an established dairy flavor language (Drake and Civille, 2003; Drake et al., 2009) previously applied to SPC34 (SPC with 34\% protein) and SPC80 (Evans et al., 2009, 2010). Panelists $(\mathrm{n}=8)$ each had more than $150 \mathrm{~h}$ of previous experience with the sensory analysis of fluid and dried whey products using the Spectrum descriptive analysis method (Meilgaard et al., 1999). All sensory testing was conducted in accordance with the North Carolina State University Institutional Review Board for Human Subjects guidelines.

Reconstituted SPC (10\% solids wt/vol) was evaluated by placing $30 \mathrm{~mL}$ in 3 -digit-coded $60-\mathrm{mL}$ lidded cups (Solo Cup Company, Champaign, IL). Preparations were conducted with the overhead lights off to avoid exposure to light. Samples were evaluated by each panelist in duplicate. Sensory data were collected on paper ballots or using Compusense 5, release 4.8 (Compusense, Guelph, Canada).

\section{GC-MS}

Selected volatile compounds in SPC80 powder were extracted by solid-phase microextraction using selective ion monitoring. Compounds were selected based on previously identified flavor-contributing compounds in serum and whey proteins (Evans et al., 2009, 2010; 
Whitson et al., 2011; Jervis et al., 2012). Compounds were then separated and identified by GC-MS using the method described by Jervis et al. (2012). Spray-dried powders were reconstituted at $10 \%$ solids (wt/vol). All samples contained $10 \%$ (wt/vol) sodium chloride (Fisher Scientific, Fairlawn, NJ) and $10 \mu \mathrm{L}$ of internal standard solution (2-methyl-3-heptanone in methanol at $81 \mathrm{mg} / \mathrm{kg}$; Sigma Aldrich, Milwaukee, WI) in 20-mL autosampler vials with steel screw-top lids containing silicone septa faced in Teflon (Microliter Analytical, Suwanee, GA). Samples were injected using a CombiPal autosampler (CTC Analytics, Zwingen, Switzerland) attached to an Agilent 6890N GC with 5973 inert mass selective detector (Agilent Technologies Inc., Santa Clara, CA). Samples were maintained at $5^{\circ} \mathrm{C}$ before fiber exposure. Samples were equilibrated at $40^{\circ} \mathrm{C}$ for 25 min before 30 -min fiber exposure of a 1-cm divinylbenzene/carboxen/polydimethylsiloxane fiber (DVB/ CAR/PDMS, Supelco, Bellefonte, PA) at $31 \mathrm{~mm}$ with 4 -s pulsed agitation at $250 \mathrm{rpm}$. Fibers were injected for $5 \mathrm{~min}$ at a depth of $50 \mathrm{~mm}$. A Zb- $5 \mathrm{~ms}$ column (30 $\mathrm{m}$ long $\times 0.25 \mathrm{~mm}$ i.d. $\times 0.25 \mu \mathrm{m}$ film thickness; Phenomenex, Torrance, CA) was used for all analyses at a constant flow rate of $1 \mathrm{~mL} / \mathrm{min}$. Compounds were identified using the National Institute of Standards and Technology (NIST) 2005 library of spectra and comparison of spectra of authentic standards injected under identical conditions. Compounds were quantified using external standard calibration curves for selected compounds. Retention indices were calculated using an alkane series from Sigma Aldrich (Van den Dool and Kratz, 1963).

Quantification of selected volatile compounds in samples was executed using 5-point external standard curves ranging from $0.50 \mu \mathrm{g} / \mathrm{kg}$ to $2 \mathrm{mg} / \mathrm{kg}$ (depending on selected compound) and integrated to an internal standard ( $81 \mathrm{mg} / \mathrm{kg}$ of 2-methyl-3-heptanone). External standard curves were prepared by pipetting 4.0 $\mathrm{mL}$ of water into $20-\mathrm{mL}$ autosampler vials with steel screw-top lids lined with silicone septa faced in Teflon (Microliter Analytical) with spiked amounts of target compounds and $10 \mu \mathrm{L}$ of internal standard; HPLCgrade water (VWR International) was used to bring the total solution volume to $5.0 \mathrm{~mL}$. Sodium chloride (Fisher Scientific) was added to the vials before the addition of water so that the total solution was $10 \%$ (wt/vol) sodium chloride.

\section{Functional Properties}

Foam Generation. The method for foam measurement was previously described by Jervis et al. (2012). Briefly, an Artisan KitchenAid mixer (KitchenAid, St. Joseph, MI) with a 4.5-quart stationary bowl and a rotating wire beater was used for foam formation. Solutions of protein $(10 \% \mathrm{wt} / \mathrm{vol}$ of protein) were rehydrated for $6 \mathrm{~h}$ at room temperature $\left(20\right.$ to $\left.24^{\circ} \mathrm{C}\right)$ on a stir plate set to $200 \mathrm{rpm}$. Solutions were refrigerated overnight at $4^{\circ} \mathrm{C}$ and tempered to $25^{\circ} \mathrm{C}$. Solutions were then adjusted to pH 7 using $1 \mathrm{~N} \mathrm{NaOH}$ (VWR International) and prepared in triplicate. A 200-mL sample of solution was whipped at speed 10 (beater rpm of 752) for $19 \mathrm{~min}$ and $36 \mathrm{~s}$ (Davis and Foegeding, 2007).

Foam Stability and Yield Stress. Foam drainage was measured using the methods of Phillips et al. (1990) and Luck et al. (2001). Foam stability was measured as the time it took for half of the prefoam mass to drain through a 6 -mm hole in a whipping bowl. The starting time for these measurements was immediately after foam formation (Davis and Foegeding, 2007). A longer drainage half-life corresponds to greater foam stability. Yield stress was conducted previously, as described by Jervis et al. (2012).

Foam Overrun. Overrun measurements were conducted immediately following yield stress measurements. Foam was removed from the bowl using a rubber spatula in a circular pattern, gently placed in a weighing dish $(100 \mathrm{~mL})$, and then weighed. This was done 10 times and the mean value was used to calculate overrun and the air phase fraction using the following equations:

$$
\begin{aligned}
& \text { Overrun }= \\
& \frac{(\text { wt. of } 100 \mathrm{~mL} \text { of solution })-(\text { wt. of } 100 \mathrm{~mL} \text { of foam })}{(\text { wt. of } 100 \mathrm{~mL} \text { of foam })} \\
& \text { Air phase fraction }(\varphi)=\frac{\% \text { overrun }}{(\% \text { overrun }+100)}
\end{aligned}
$$

Foam measurements were done in triplicate (Dickinson, 1999; Wilde, 2000; Davis and Foegeding, 2007).

Solubility. Solubility was measured as described by Jervis et al. (2012). The SPC80 was rehydrated to $10 \%$ protein (wt/vol) as described for foam generation. Solutions were then adjusted using $1 \mathrm{~N} \mathrm{HCl}$ or $1 N \mathrm{NaOH}$ to $\mathrm{pH} 3,4,5,6$, or 7 and brought to a total volume of $100 \mathrm{~mL}$ with deionized water, resulting in 10\% (wt/ vol) protein solutions. Turbidity and solubility were measured and recorded on samples both before and after centrifugation. Turbidity was measured using a turbidimeter (2100AN, Hach Co., Loveland, CO), and solubility was measured using the micro bicinchoninic acid assay. After these measurements were complete, solutions were then centrifuged at $16,500 \times g$ for 10 min (model RC5B, Thermo Scientific, Asheville, NC). Turbidity and solubility of the samples were measured once again, but this time on the supernatants. 
Table 1. Mean $(\mathrm{n}=3)$ composition (\% by weight) and $\mathrm{pH}$ of the microfiltration permeate with and without annatto color added to the milk followed by no bleaching, bleaching with benzoyl peroxide (BP, $50 \mathrm{mg} / \mathrm{kg}$ ), or bleaching with hydrogen peroxide (HP, $500 \mathrm{mg} / \mathrm{kg})^{1}$ before spray drying

\begin{tabular}{lcccc}
\hline & & \multicolumn{2}{l}{ Microfiltration permeate } \\
\cline { 2 - 5 } Treatment & TS & Fat & $\mathrm{CP}^{2}$ & $\mathrm{pH}$ \\
\hline No color & 3.27 & 0.001 & 0.73 & 6.71 \\
No color + BP & 3.17 & 0.004 & 0.72 & 6.66 \\
No color + HP & 3.22 & 0.003 & 0.70 & 6.71 \\
Annatto & 3.25 & 0.004 & 0.72 & 6.72 \\
Annatto + BP & 3.31 & 0.005 & 0.72 & 6.71 \\
Annatto + HP & 3.33 & 0.007 & 0.73 & 0.73 \\
$\mathrm{R}^{2}$ & 0.71 & 0.48 & 0.49 & 0.057 \\
SEM & 0.084 & 0.003 & 0.029 & 0.036 \\
${ }^{1}$ No differences in means within the same column were detected $(P>0.05)$. & & \\
${ }^{2}$ Total nitrogen $\times 6.38$. & & &
\end{tabular}

Heat Stability. Heat stability measurements were conducted as described by Jervis et al. (2012). The SPC80 was rehydrated to $5 \%(\mathrm{wt} / \mathrm{vol})$ and $10 \%$ protein $(\mathrm{wt} / \mathrm{vol}$ ) as described for foam generation. Solutions were then adjusted using $1 \mathrm{~N} \mathrm{NaOH}$ to $\mathrm{pH} 7$ and brought to volume. Solutions were placed in a heated water bath at $90^{\circ} \mathrm{C}$ for $0,10,20$, or 30 min. Turbidity and micro bicinchoninic acid measurements of solubility were taken before and after centrifugation at room temperature and calculated as described previously. The supernatant was then collected and brought to $\mathrm{pH} 4.6$ using $1 \mathrm{~N} \mathrm{HCl}$. Turbidity and solubility were measured on the $\mathrm{pH} 4.6$ supernatant before and after centrifugation. All solutions were measured in quadruplicate.

\section{Statistical Analyses}

All data were analyzed by ANOVA using PROC GLM (general linear model, SAS version 8.02, 1999 2001; SAS Institute Inc., Cary, NC). Tukey's honestly significant difference was conducted as a post hoc test. To determine if composition or $\mathrm{pH}$ differed $(P<0.05)$ among color and bleaching treatments for MF permeates, the general linear model was dependent variable $=$ bleach + color + replicate + bleach $\times$ color + error . The same general linear model was used to determine if composition or Hunter color values differed $(P<0.05)$ among color and bleaching treatments for SPC80 powders. Principal component analysis was applied to the correlation matrix of sensory and volatile component data to visualize how bleaching agent differentiated the SPC80 treatments based upon sensory attributes or volatile components.

\section{RESULTS}

\section{Chemical and Mineral Analyses}

No differences in moisture, protein, or fat were detected among treatments $(P>0.05)$ with moisture 4.81 $\pm 0.24 \%$, protein (dry basis) $83.17 \pm 0.42 \%$, and fat (dry basis) $0.526 \pm 0.05 \%$ (Tables 1 and 2). No differences in potassium were detected between treatments $(P>0.05$; Table 3$)$. A significant effect of bleach $(P$

Table 2. Mean ( $\mathrm{n}=3$ ) composition (\% by weight, on a dry and wet basis) of spray-dried $80 \%$ serum protein concentrate (SPC80) with and without annatto color added to the milk followed by no bleaching, bleaching with benzoyl peroxide $\left(\mathrm{BP}, 50 \mathrm{mg} / \mathrm{kg}\right.$ ), or bleaching with hydrogen peroxide $(\mathrm{HP}, 500 \mathrm{mg} / \mathrm{kg})^{1}$

\begin{tabular}{|c|c|c|c|c|c|}
\hline \multirow[b]{2}{*}{ Treatment } & \multirow[b]{2}{*}{ Moisture } & \multicolumn{2}{|c|}{ Dry basis } & \multicolumn{2}{|c|}{ Wet basis } \\
\hline & & Fat & $\mathrm{CP}^{2}$ & Fat & $\mathrm{CP}$ \\
\hline No color & 4.96 & 0.62 & 83.07 & 0.59 & 78.95 \\
\hline No color $+\mathrm{BP}$ & 5.07 & 0.52 & 83.35 & 0.49 & 79.12 \\
\hline No color $+\mathrm{HP}$ & 4.73 & 0.52 & 83.89 & 0.50 & 79.91 \\
\hline Annatto & 4.52 & 0.53 & 82.88 & 0.51 & 79.13 \\
\hline Annatto + BP & 5.02 & 0.45 & 82.71 & 0.43 & 78.55 \\
\hline Annatto + HP & 4.54 & 0.51 & 83.09 & 0.49 & 79.31 \\
\hline $\mathrm{R}^{2}$ & 0.25 & 0.73 & 0.78 & 0.72 & 0.70 \\
\hline SEM & 0.326 & 0.043 & 0.308 & 0.041 & 0.342 \\
\hline
\end{tabular}

${ }^{1}$ No differences in means within the same column were detected $(P>0.05)$.

${ }^{2}$ Total nitrogen $\times 6.38$. 
Table 3. Mean $(\mathrm{n}=3)$ mineral composition $(\mathrm{mg} / \mathrm{kg}$, calculated on a dry basis) of spray-dried $80 \%$ serum protein concentrate (SPC80) with and without annatto color added to the milk followed by no bleaching, bleaching with benzoyl peroxide (BP, $50 \mathrm{mg} / \mathrm{kg}$ ), or bleaching with hydrogen peroxide (HP, $500 \mathrm{mg} / \mathrm{kg}$ )

\begin{tabular}{|c|c|c|c|c|c|c|c|}
\hline Treatment & $\mathrm{P}$ & $\mathrm{Ca}$ & $\mathrm{K}$ & $\mathrm{Mg}$ & $\mathrm{S}$ & $\mathrm{Na}$ & $\mathrm{Fe}$ \\
\hline No color & $0.407^{\mathrm{a}}$ & $0.577^{\mathrm{a}}$ & $0.697^{\mathrm{a}}$ & $0.070^{\mathrm{a}}$ & $1.13^{\mathrm{bc}}$ & $1,800^{\mathrm{ab}}$ & $9.06^{\mathrm{a}}$ \\
\hline No color $+\mathrm{BP}$ & $0.377^{\mathrm{b}}$ & $0.543^{\mathrm{bc}}$ & $0.667^{\mathrm{a}}$ & $0.070^{\mathrm{a}}$ & $1.12^{\mathrm{c}}$ & $1,693^{\mathrm{d}}$ & $8.23^{\mathrm{ab}}$ \\
\hline $\mathrm{No}$ color $+\mathrm{HP}$ & $0.347^{\mathrm{c}}$ & $0.493^{\mathrm{d}}$ & $0.707^{\mathrm{a}}$ & $0.060^{\mathrm{b}}$ & $1.14^{\mathrm{a}}$ & $1,803^{\mathrm{ab}}$ & $6.97^{\mathrm{bc}}$ \\
\hline Annatto & $0.390^{\mathrm{ab}}$ & $0.567^{\mathrm{ab}}$ & $0.677^{\mathrm{a}}$ & $0.070^{\mathrm{a}}$ & $1.12^{\mathrm{bc}}$ & $1,727^{\mathrm{cd}}$ & $8.98^{\mathrm{a}}$ \\
\hline Annatto $+\mathrm{BP}$ & $0.387^{\mathrm{ab}}$ & $0.567^{\mathrm{ab}}$ & $0.693^{\mathrm{a}}$ & $0.070^{\mathrm{a}}$ & $1.13^{\mathrm{ab}}$ & $1,764^{\mathrm{bc}}$ & $8.65^{\mathrm{a}}$ \\
\hline Annatto $+\mathrm{HP}$ & $0.363^{\mathrm{bc}}$ & $0.520^{\mathrm{cd}}$ & $0.723^{\mathrm{a}}$ & $0.067^{\mathrm{a}}$ & $1.15^{\mathrm{a}}$ & $1,851^{\mathrm{a}}$ & $6.17^{\mathrm{c}}$ \\
\hline $\mathrm{R}^{2}$ & 0.94 & 0.97 & 0.86 & 0.93 & 0.98 & 0.97 & 0.95 \\
\hline SE & 0.007 & 0.007 & 0.019 & 0.001 & 0.004 & 13.7 & 0.33 \\
\hline
\end{tabular}

${ }^{\mathrm{a}-\mathrm{d}}$ Means in the same column not sharing a common superscript are different $(P<0.05)$.

$<0.05)$ was found for all other minerals, with higher amounts of sulfur and sodium found in HP samples compared with BP and unbleached SPC80 (Table 3). The HP-treated SPC80 contained lower amounts of phosphorus, calcium, magnesium, and iron compared with the BP-bleached and control treatments $(P<$ 0.05; Table 3). Lower amounts of iron in HP-treated samples compared with other bleached and unbleached treatments were previously noted in WPC80 (Jervis et al., 2012).

\section{Color Analysis of Liquid and Spray-Dried SPC80}

The addition of color (annatto) had a significant effect on Hunter $\mathrm{L}$, a, and $\mathrm{b}$ values, as expected $(P<$ 0.05; Table 4). Bleaching, regardless of added color or bleach treatment, increased the whiteness (L value) of the powders $(P<0.05)$. Hydrogen peroxide treatments, with and without added annatto color, had higher L values than $\mathrm{BP}$ treatments (with and without added color; $P<0.05$ ). The yellowness of SPC80 bleached with either $\mathrm{HP}$ or BP was lower than that of SPC80 with annatto with no bleach in liquids and powders $(P$ $<0.05)$. The BP-bleached liquid and powdered SPC80 with added annatto had lower $\mathrm{b}$ values in both liquid and powder forms compared with the HP and no bleach treatments with added color $(P<0.05$; Table 4$)$. These findings were consistent with a previous study with WPC80 (Jervis et al., 2012).

\section{Norbixin Extraction and Quantification}

Both bleach treatments reduced norbixin concentration $(P<0.05$; Table 5$)$. The BP-bleached SPC80 with added annatto contained less residual norbixin than SPC80 bleached by HP with added annatto $(P<0.05)$. Regardless of whether annatto was added, the amount of residual norbixin in BP-bleached SPC80 did not differ from the control with no added annatto $(P>0.05)$. Hydrogen peroxide reduced norbixin by $50 \%$ compared with the control with added annatto, whereas BP reduced norbixin by $92 \%$ compared with the control with added annatto. Previous studies with fluid whey bleaching have also demonstrated that BP bleaching resulted in greater destruction of norbixin than did HP bleaching (Jervis et al., 2012; Listiyani et al., 2011, 2012).

\section{Descriptive Sensory Analysis}

Sensory profiles of SPC80 were distinct (Table 6). The HP-bleached SPC80, regardless of added annatto, was higher in aroma intensity, cardboard, and fatty flavors $(P<0.05)$ than the SPC80 bleached with BP or

Table 4. Mean $(\mathrm{n}=3)$ color ( $\mathrm{L}$, a, and b values) of liquid $(10 \% \mathrm{wt} / \mathrm{vol}$ powders) and spray-dried $80 \%$ serum protein concentrate (SPC80) with and without annatto color added to the milk followed by no bleaching, bleaching with benzoyl peroxide (BP, $50 \mathrm{mg} / \mathrm{kg}$ ), or bleaching with hydrogen peroxide (HP, $500 \mathrm{mg} / \mathrm{kg}$ )

\begin{tabular}{|c|c|c|c|c|c|}
\hline \multirow[b]{2}{*}{ Treatment } & \multirow{2}{*}{$\frac{\text { L (lightness) }}{\text { Powder }}$} & \multicolumn{2}{|c|}{ a (red-green) } & \multicolumn{2}{|c|}{ b (yellow-blue) } \\
\hline & & Liquid & Powder & Liquid & Powder \\
\hline No color & $88.6^{\mathrm{d}}$ & $5.15^{\mathrm{abc}}$ & $1.59^{\mathrm{c}}$ & $13.9^{\mathrm{b}}$ & $7.21^{\mathrm{cd}}$ \\
\hline No color $+\mathrm{BP}$ & $89.3^{\mathrm{c}}$ & $3.23^{\mathrm{bc}}$ & $1.16^{\mathrm{cd}}$ & $9.9^{\mathrm{b}}$ & $6.48^{\mathrm{d}}$ \\
\hline No color $+\mathrm{HP}$ & $91.2^{\mathrm{a}}$ & $3.20^{\mathrm{bc}}$ & $0.75^{\mathrm{d}}$ & $10.4^{\mathrm{b}}$ & $6.00^{\mathrm{d}}$ \\
\hline Annatto & $87.7^{\mathrm{e}}$ & $8.13^{\mathrm{a}}$ & $3.36^{\mathrm{a}}$ & $23.3^{\mathrm{a}}$ & $14.7^{\mathrm{a}}$ \\
\hline Annatto $+\mathrm{BP}$ & $89.3^{\mathrm{c}}$ & $2.29^{\mathrm{c}}$ & $1.42^{\mathrm{c}}$ & $9.8^{\mathrm{b}}$ & $8.24^{\mathrm{c}}$ \\
\hline Annatto $+\mathrm{HP}$ & $89.9^{\mathrm{b}}$ & $5.82^{\mathrm{ab}}$ & $2.54^{\mathrm{b}}$ & $21.8^{\mathrm{a}}$ & $12.8^{\mathrm{b}}$ \\
\hline $\mathrm{R}^{2}$ & $>0.99$ & 0.85 & 0.98 & 0.93 & 0.99 \\
\hline SEM & 0.083 & 0.673 & 0.102 & 1.286 & 0.299 \\
\hline
\end{tabular}

${ }^{\mathrm{a}-\mathrm{e}}$ Means in the same column not sharing a common superscript are different $(P<0.05)$. 
Table 5. Mean $(\mathrm{n}=3)$ norbixin recovery ( $\mathrm{mg}$ of norbixin $/ \mathrm{kg}$ of TS) from $80 \%$ serum protein concentrate (SPC80) with and without annatto color added to the milk followed by no bleaching, bleaching with benzoyl peroxide (BP, $50 \mathrm{mg} / \mathrm{kg}$ ), or bleaching with hydrogen peroxide (HP, $500 \mathrm{mg} / \mathrm{kg}$ )

\begin{tabular}{lcccccccc}
\hline \multicolumn{10}{c}{ Treatment } \\
\cline { 2 - 5 } Item & No color & $\begin{array}{c}\text { No color } \\
+\mathrm{BP}\end{array}$ & $\begin{array}{c}\text { No color } \\
+\mathrm{HP}\end{array}$ & Annatto & $\begin{array}{c}\text { Annatto } \\
+\mathrm{BP}\end{array}$ & $\begin{array}{c}\text { Annatto } \\
+\mathrm{HP}\end{array}$ & $\mathrm{R}^{2}$ & SE \\
\hline Norbixin & $1.62^{\text {cd }}$ & $1.69^{\mathrm{c}}$ & $0.69^{\mathrm{d}}$ & $15.03^{\mathrm{a}}$ & $1.26^{\text {cd }}$ & $7.38^{\mathrm{b}}$ & 0.98 & 0.33 \\
\hline a-d Means in the same row not sharing a common
\end{tabular}

${ }^{\mathrm{a}-\mathrm{d}}$ Means in the same row not sharing a common superscript are different $(P<0.05)$.

unbleached SPC80. Sweet aromatic and cooked/canned corn flavors were higher and cardboard flavor was lower in the unbleached SPC80, regardless of added annatto, compared with those that were bleached with HP or BP $(P<0.05)$.

\section{GC-MS}

Among bleach types, SPC80 was distinct in volatile compound profiles (Figure 1). The HP-bleached SPC80, either colored or uncolored, contained higher concentrations of lipid oxidation compounds than the BP-bleached SPC80 $(P<0.05)$. Compounds found at higher amounts in HP-treated SPC80 compared with either BP-bleached or unbleached SPC80 were hexanal, heptanal, nonanal, benzaldehyde, and 2,3-octadienone $(P<0.05$; Table 7$)$. Bleached SPC80 (BP or HP) were higher in octanal and 2-pentyl furan than unbleached SPC80.

\section{Functional Properties}

Foam Stability, Yield Stress, and Overrun. Differences in foam stability were detected among bleach treatments $(P<0.05$; Table 8$)$. Foams from bleached SPC80 (BP or HP) were more stable than the unbleached controls $(P<0.05)$, and foams from BP- bleached SPC80 were more stable than those bleached with HP $(P<0.05)$. Foams from unbleached SPC80 were more stable with added annatto than without $(P$ $<0.05)$.

Color and bleach affected the yield stress of foams (Table 8). The SPC80 with added annatto, regardless of bleach treatment, had lower yield stress compared with those without added annatto $(P<0.05)$. The SPC80 treated with HP had lower yield stress than BP and control SPC80, regardless of color $(P<0.05)$.

Average overrun was 1,233.2 $\pm 40.7 \%$, and no differences were detected among SPC80 treatments $(P>$ $0.05 ; \mathrm{R}^{2}=0.28 ; \mathrm{SE}=61.4$; data not shown).

Solubility. Solubility of SPC80 with no heat treatment differed among bleach treatments within a specific $\mathrm{pH}$ value $(P<0.05$; Figure 2$)$. At $\mathrm{pH} 3$, unbleached SPC80, with or without annatto, were less soluble than those bleached by $\mathrm{HP}$ or $\mathrm{BP}(P<0.05)$. At $\mathrm{pH} 4$, unbleached SPC 80 and those bleached with BP, with or without annatto, were less soluble than those bleached by HP $(P<0.05)$. At $\mathrm{pH} 5$, bleached SPC80 (HP or $\mathrm{BP})$, regardless of color, were less soluble than unbleached SPC80 $(P<0.05)$. No differences in solubility were detected at $\mathrm{pH} 6$ or $7(P>0.05)$.

Heat Stability. Serum protein powders bleached with HP, both colored and uncolored, at 10\% (wt/vol) protein were more soluble after $10 \mathrm{~min}$ at $90^{\circ} \mathrm{C}$ than

Table 6. Mean ( $\mathrm{n}=3$ replicates with 10 panelists) sensory attributes ${ }^{1}$ of $80 \%$ serum protein concentrate (SPC80) with and without annatto color added to the milk followed by no bleaching, bleaching with benzoyl peroxide (BP, $50 \mathrm{mg} / \mathrm{kg}$ ), or bleaching with hydrogen peroxide (HP, $500 \mathrm{mg} / \mathrm{kg}$ )

\begin{tabular}{lccccccc}
\hline Treatment & $\begin{array}{c}\text { Aroma } \\
\text { intensity }\end{array}$ & $\begin{array}{c}\text { Sweet } \\
\text { aromatic }\end{array}$ & $\begin{array}{c}\text { Cooked/ } \\
\text { canned corn }\end{array}$ & Fatty & Cardboard & Bitter & Astringency \\
\hline No color & $2.2^{\mathrm{c}}$ & $1.7^{\mathrm{a}}$ & $3.3^{\mathrm{a}}$ & $\mathrm{ND}^{2}$ & $0.6^{\mathrm{d}}$ & $0.6^{\mathrm{a}}$ & $2.2^{\mathrm{d}}$ \\
No color + BP & $2.3^{\mathrm{b}}$ & $0.5^{\mathrm{b}}$ & $2.0^{\mathrm{bc}}$ & $1.5^{\mathrm{b}}$ & $1.6^{\mathrm{c}}$ & $0.6^{\mathrm{a}}$ & $2.6^{\mathrm{a}}$ \\
No color + HP & $2.6^{\mathrm{a}}$ & $\mathrm{ND}$ & $2.0^{\mathrm{bc}}$ & $1.8^{\mathrm{a}}$ & $2.5^{\mathrm{b}}$ & $0.7^{\mathrm{a}}$ & $2.6^{\mathrm{a}}$ \\
Annatto & $2.3^{\mathrm{b}}$ & $1.8^{\mathrm{a}}$ & $3.1^{\mathrm{a}}$ & $\mathrm{ND}$ & $0.7^{\mathrm{d}}$ & $0.6^{\mathrm{a}}$ & $2.3^{\mathrm{bc}}$ \\
Annatto + BP & $2.0^{\mathrm{c}}$ & $0.9^{\mathrm{b}}$ & $2.0^{\mathrm{bc}}$ & $1.5^{\mathrm{b}}$ & $1.9^{\mathrm{c}}$ & $0.8^{\mathrm{a}}$ & $2.4^{\mathrm{b}}$ \\
Annatto + HP & $2.6^{\mathrm{a}}$ & $\mathrm{ND}$ & $1.7^{\mathrm{c}}$ & $1.9^{\mathrm{a}}$ & $2.8^{\mathrm{a}}$ & $0.6^{\mathrm{a}}$ & $2.5^{\mathrm{ab}}$ \\
$\mathrm{R}^{2}$ & 0.66 & 0.92 & 0.90 & 0.94 & 0.93 & 0.78 & 0.77 \\
$\mathrm{SE}$ & 0.11 & 0.12 & 0.11 & 0.11 & 0.12 & 0.07 & 0.05 \\
\hline
\end{tabular}

${ }^{\mathrm{a}-\mathrm{d}}$ Means in the same column not sharing a common superscript are different $(P<0.05)$.

${ }^{1}$ Intensities were scored on a 0 to 15 universal scale, where $0=$ none and $15=$ very high intensity (Meilgaard et al., 1999). Dried whey ingredient intensities usually fall between 0 and 4 on this scale (Drake and Civille, 2003; Wright et al., 2009).

${ }^{2}$ Not detected. 
Biplot (axes F1 and F2: $77 \%$ )

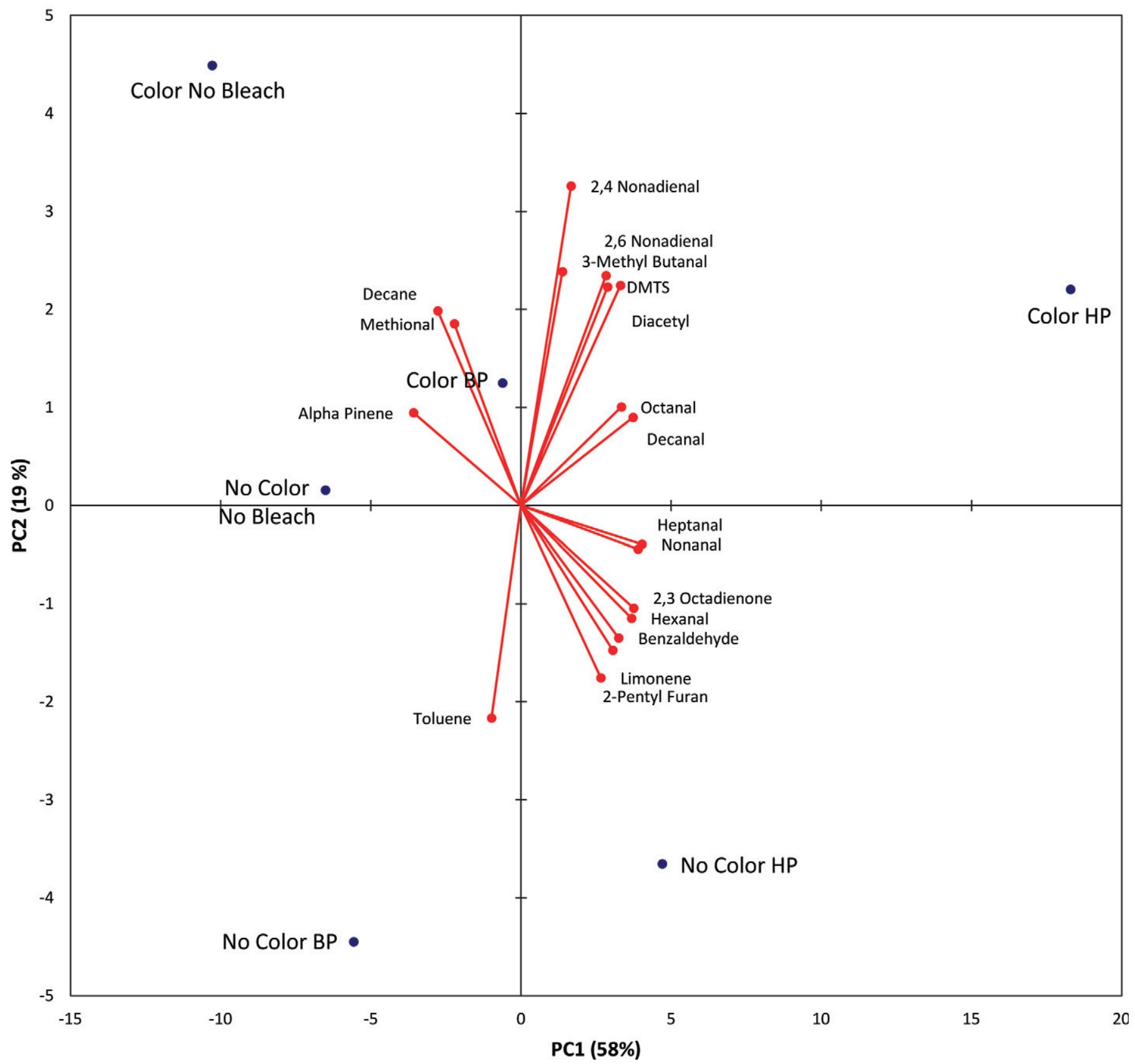

Figure 1. Principal component biplot of relative abundance of volatile compounds found in $80 \%$ serum protein concentrate (SPC 80 ) with and without annatto color added to the milk followed by no bleaching, bleaching with benzoyl peroxide (BP, $50 \mathrm{mg} / \mathrm{kg})$, or bleaching with hydrogen peroxide (HP, $500 \mathrm{mg} / \mathrm{kg})$. PC1 and $\mathrm{PC} 2=$ principal components 1 and 2 . DMTS = dimethyl trisulfide. Color version available in the online PDF.

colored or uncolored BP-bleached SPC80 at $\mathrm{pH} 4.6$ $(P<0.05$; Figure 3). All SPC80, whether colored or uncolored, bleached or not bleached, gelled after $20 \mathrm{~min}$ of heating and $\mathrm{pH}$ adjustment to 4.6. No differences in heat stability were observed at $5 \%(\mathrm{wt} / \mathrm{vol})$ protein at $\mathrm{pH} 7$ and $\mathrm{pH} 4.6(P>0.05$; results not shown).

\section{DISCUSSION}

\section{Flavor}

Compositionally, all SPC80 powders were similar, but visually, their appearance differed. Consistent with 


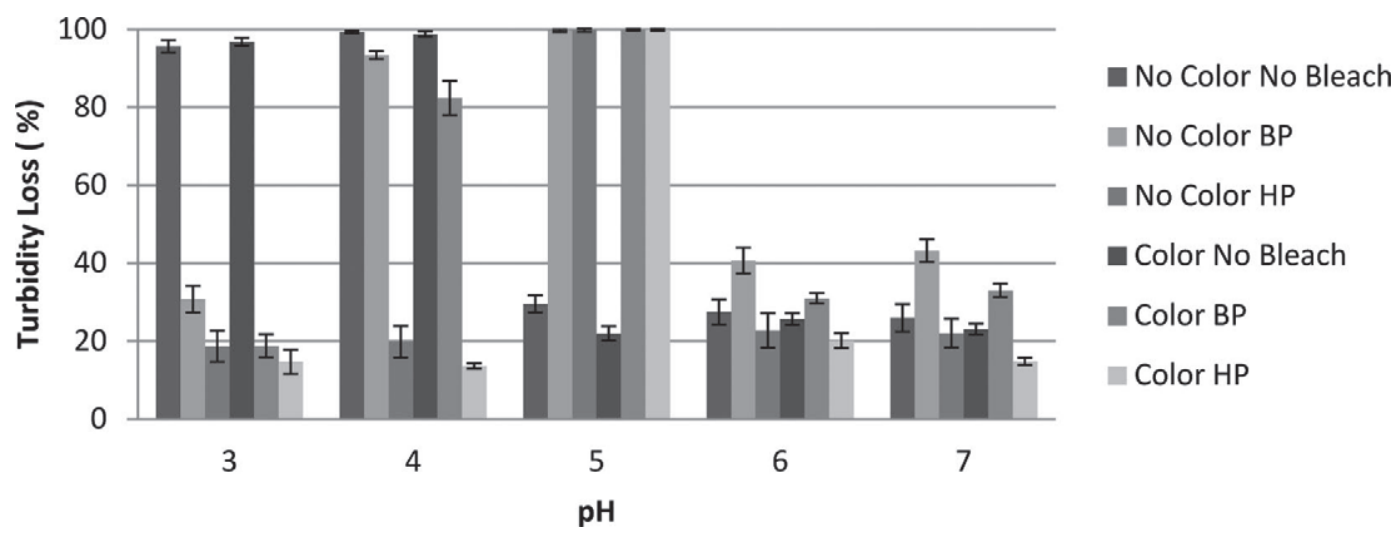

Figure 2. Mean percentage insolubility of $80 \%$ serum protein concentrate (SPC 80 ) at $10 \%$ (wt/vol) protein using turbidity loss (low turbidity loss indicates high solubility). The SPC 80 was manufactured with and without annatto color added to the milk followed by no bleaching, bleaching with benzoyl peroxide (BP, $50 \mathrm{mg} / \mathrm{kg}$ ), or bleaching with hydrogen peroxide (HP, $500 \mathrm{mg} / \mathrm{kg}$ ).

previous studies, BP bleached better than HP. Norbixin values and $\mathrm{b}$ values were in agreement: as norbixin increased, so did b values. Flavor effects of BP and HP bleaching have been consistently reported in the literature for WPC34 and WPC80 (Jervis et al., 2012; Listiyani et al., 2012), and BP and HP had similar effects on flavor of SPC80.

Dried dairy ingredients are expected to be bland and flavorless so as to not influence product flavor and acceptability (Drake, 2006). In the United States, a large volume of whey comes from Cheddar cheese in which annatto, an orange carotenoid pigment composed of bixin and norbixin, is added to the milk to give the cheese a characteristic orange color (Kang et al., 2010). Some of this colorant is present in the whey and the whey must be bleached to remove the color (Kang et al., 2010). Outside the United States, annatto cheese colorant is less prevalently used and the need for bleaching of fluid whey less urgent. Bleaching of fluid whey increases lipid oxidation volatile compounds and results in off-flavors that are present in spray-dried whey proteins, thus influencing consumer acceptability of final products (Croissant et al., 2009; Jervis et al., 2012; Listiyani et al., 2012). Serum protein concentrates are lower in fat (0.53 vs. $4.67 \%$ on a dry weight basis) than WPC (Evans et al., 2009, 2010) because the fat remaining in skim milk is retained in the retentate of the MF process, whereas the serum proteins pass

Table 7. Mean $(\mathrm{n}=3)$ relative abundance $(\mu \mathrm{g} / \mathrm{kg})$ of selected volatile compounds of spray-dried $80 \%$ serum protein concentrate $(\mathrm{SPC} 80)$ with and without annatto color added to the milk followed by no bleaching, bleaching with benzoyl peroxide (BP, $50 \mathrm{mg} / \mathrm{kg}$ ), or bleaching with hydrogen peroxide (HP, $500 \mathrm{mg} / \mathrm{kg}$ ) isolated using solid-phase microextraction

\begin{tabular}{|c|c|c|c|c|c|c|c|c|}
\hline Compound & Annatto & $\begin{array}{c}\text { Annatto } \\
+\mathrm{BP}\end{array}$ & $\begin{array}{c}\text { Annatto } \\
+\mathrm{HP}\end{array}$ & No color & $\begin{array}{l}\text { No color } \\
+\mathrm{BP}\end{array}$ & $\begin{array}{l}\text { No color } \\
+\mathrm{HP}\end{array}$ & $\mathrm{R}^{2}$ & $\mathrm{SE}$ \\
\hline 2,3 Octanedione & $1.09^{\mathrm{c}}$ & $3.69^{\mathrm{b}}$ & $11.50^{\mathrm{a}}$ & $0.90^{\mathrm{c}}$ & $4.69^{\mathrm{b}}$ & $9.73^{\mathrm{a}}$ & 0.78 & 0.70 \\
\hline 2,4 Nonadienal & $0.986^{\mathrm{a}}$ & $1.05^{\mathrm{a}}$ & $0.961^{\mathrm{a}}$ & $0.798^{\mathrm{a}}$ & $0.664^{\mathrm{a}}$ & $0.758^{\mathrm{a}}$ & 0.05 & 0.30 \\
\hline 2,6 Nonadienal & $2.05^{\mathrm{a}}$ & $2.44^{\mathrm{a}}$ & $2.90^{\mathrm{a}}$ & $2.28^{\mathrm{a}}$ & $1.69^{\mathrm{a}}$ & $1.86^{\mathrm{a}}$ & 0.06 & 0.12 \\
\hline 2-Pentyl furan ${ }^{1}$ & $9.97^{\mathrm{b}}$ & $172^{\mathrm{a}}$ & $191^{\mathrm{a}}$ & $6.99^{\mathrm{b}}$ & $149^{\mathrm{a}}$ & $156^{\mathrm{a}}$ & 0.51 & 15 \\
\hline 3-Methylbutanal ${ }^{1}$ & $28.1^{\mathrm{a}}$ & $20.4^{\mathrm{ab}}$ & $26.6^{\mathrm{a}}$ & $13.5^{\mathrm{b}}$ & $20.4^{\mathrm{ab}}$ & $17.2^{\mathrm{b}}$ & 0.28 & 2.9 \\
\hline$\alpha$-Pinene & $6.78^{\mathrm{a}}$ & $5.63^{\mathrm{a}}$ & $4.82^{\mathrm{a}}$ & $5.97^{\mathrm{a}}$ & $5.85^{\mathrm{a}}$ & $5.60^{\mathrm{a}}$ & 0.04 & 0.80 \\
\hline Benzaldehyde $^{1}$ & $11.8^{\mathrm{d}}$ & $11.9^{\mathrm{d}}$ & $23.0^{\mathrm{b}}$ & $11.9^{\mathrm{d}}$ & $14.5^{\mathrm{c}}$ & $25.7^{\mathrm{a}}$ & 0.87 & 2.3 \\
\hline Decanal $^{1}$ & $3.23^{\mathrm{b}}$ & $5.78^{\mathrm{ab}}$ & $7.83^{\mathrm{a}}$ & $6.27^{\mathrm{ab}}$ & $3.56^{\mathrm{b}}$ & $5.14^{\mathrm{ab}}$ & 0.23 & 0.71 \\
\hline Decane & $32.8^{\mathrm{a}}$ & $28.9^{\mathrm{ab}}$ & $19.2^{\mathrm{ab}}$ & $33.4^{\mathrm{a}}$ & $25.4^{\mathrm{ab}}$ & $12.7^{\mathrm{b}}$ & 0.17 & 0.36 \\
\hline Diacetyl & $1.06^{\mathrm{a}}$ & $1.06^{\mathrm{a}}$ & $1.79^{\mathrm{a}}$ & $0.927^{\mathrm{a}}$ & $0.706^{\mathrm{a}}$ & $0.936^{\mathrm{a}}$ & 0.06 & 0.15 \\
\hline DMTS & $1.57^{\mathrm{a}}$ & $1.36^{\mathrm{a}}$ & $1.64^{\mathrm{a}}$ & $1.24^{\mathrm{a}}$ & $1.26^{\mathrm{a}}$ & $1.40^{\mathrm{a}}$ & 0.06 & 0.19 \\
\hline Heptanal $^{1}$ & $4.59^{\mathrm{d}}$ & $9.35^{\mathrm{cd}}$ & $34.6^{\mathrm{a}}$ & $3.97^{\mathrm{d}}$ & $10.7^{\mathrm{c}}$ & $24.7^{\mathrm{b}}$ & 0.79 & 1.9 \\
\hline Hexanal $^{1}$ & $2.59^{\mathrm{c}}$ & $78.0^{\mathrm{b}}$ & $308^{\mathrm{a}}$ & $2.93^{\mathrm{c}}$ & $104^{\mathrm{b}}$ & $290^{\mathrm{a}}$ & 0.78 & 19 \\
\hline Limonene & $1.12^{\mathrm{a}}$ & $1.79^{\mathrm{a}}$ & $2.21^{\mathrm{a}}$ & $2.14^{\mathrm{a}}$ & $1.89^{\mathrm{a}}$ & $1.98^{\mathrm{a}}$ & 0.10 & 0.25 \\
\hline Methional & $2.60^{\mathrm{a}}$ & $1.85^{\mathrm{ab}}$ & $1.43^{\mathrm{b}}$ & $1.49^{\mathrm{ab}}$ & $1.85^{\mathrm{ab}}$ & $1.95^{\mathrm{ab}}$ & 0.13 & 0.25 \\
\hline Nonanal $^{1}$ & $4.34^{\mathrm{d}}$ & $11.0^{\mathrm{bc}}$ & $21.8^{\mathrm{a}}$ & $7.13^{\mathrm{cd}}$ & $9.44^{\mathrm{cd}}$ & $15.2^{\mathrm{b}}$ & 0.50 & 1.6 \\
\hline Octanal $^{1}$ & $3.92^{\mathrm{ab}}$ & $4.73^{\mathrm{ab}}$ & $5.16^{\mathrm{a}}$ & $2.69^{\mathrm{b}}$ & $4.72^{\mathrm{ab}}$ & $4.95^{\mathrm{a}}$ & 0.14 & 0.61 \\
\hline Toluene & $8.44^{\mathrm{b}}$ & $7.88^{\mathrm{b}}$ & $7.02^{\mathrm{b}}$ & $5.51^{\mathrm{b}}$ & $16.6^{\mathrm{a}}$ & $7.25^{\mathrm{b}}$ & 0.39 & 1.2 \\
\hline
\end{tabular}

${ }^{\mathrm{a}-\mathrm{d}}$ Means in same row not sharing a common superscript are different $(P<0.05)$.

${ }^{1}$ Quantified using external standard curves to yield concentration. 


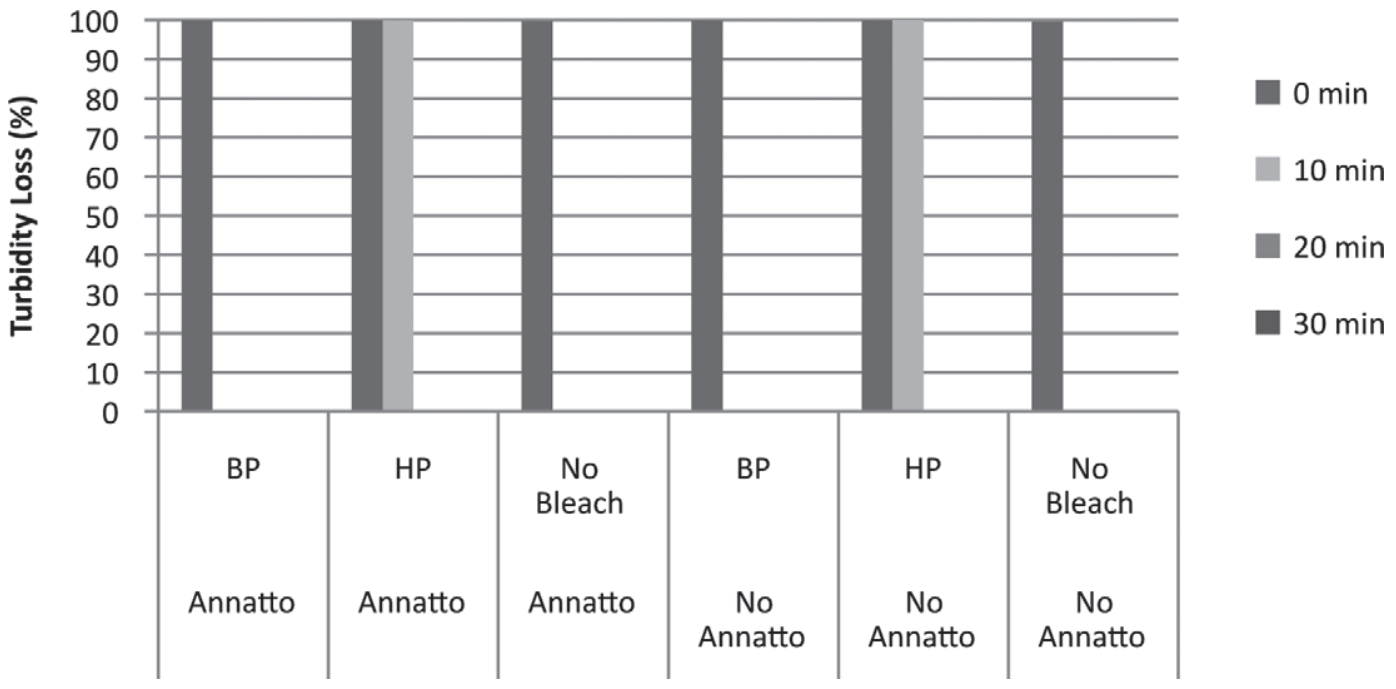

Figure 3. Mean percentage insolubility of $80 \%$ serum protein concentrate (SPC80) at pH 4.6 and $10 \%$ (wt/vol) protein heated for 0, 10, 20, and $30 \mathrm{~min}$ at $90^{\circ} \mathrm{C}$ measured using turbidity loss (low turbidity loss indicates high solubility). The SPC 80 were manufactured with and without annatto color added to the milk followed by no bleaching, bleaching with benzoyl peroxide (BP, $50 \mathrm{mg} / \mathrm{kg}$ ), or bleaching with hydrogen peroxide $(\mathrm{HP}, 500 \mathrm{mg} / \mathrm{kg}$ ). Solutions not represented in graph gelled and therefore could not be measured.

into the permeate. During WPC production, the fat not removed from whey is concentrated by UF and DF in the WPC retentate. The high content of fat in WPC has a negative effect on flavor and provides a reservoir for increased lipid oxidation compounds compared with SPC (Evans et al., 2010; Liaw et al., 2010). Further, the starter culture contributes to elevated lipid oxidation compounds in fluid whey and subsequent increased lipid oxidation during processing (Campbell et al., 2011a,b; Liaw et al., 2010, 2011). Serum proteins contain lower amounts of volatile compounds and lower intensities of flavors commonly found in WPC due to the absence of starter culture and cheese-making residuals. However, bleaching significantly affects flavor in SPC.

Consistent with results in WPC80 (Jervis et al., 2012), SPC80 bleached with HP were higher in fatty and cardboard flavors than those unbleached or bleached with BP $(P<0.05)$. Cardboard and fatty flavors have been attributed to increased volatile lipid oxidation compounds (Wright et al., 2009; Whitson et al., 2010, 2011; Jervis et al., 2012). The HP-bleached SPC80 were higher in hexanal, heptanal, nonanal, decanal, 2-pentyl furan, 2,3-octadienone, and benzaldehyde compared with the other SPC80 treatments $(P<0.05$; Figure 1$)$. In HP-bleached SPC80, the volatile compound with the highest concentration was hexanal. Although hexanal is not directly attributed to cardboard off-flavors, it is a good indicator of lipid oxidation (Whitson et al., 2010). Hexanal can be created by multiple pathways during lipid oxidation (Frankel, 2005). The BPbleached SPC80 contained lower levels of hexanal than HP-bleached SPC80 $(P<0.05)$; however, lower still were levels in the unbleached SPC80. Benzoyl peroxide has a lower oxidizing potential than HP (Jervis et al., 2012; Listiyani et al., 2012). The increase in dimethyl disulfide and the presence of cabbage/sulfur aroma in HP-treated proteins were the key distinguishing characteristics in BP-bleached compared with HP-bleached WPC80 (Jervis et al., 2012). Volatile compound types and relative differences between $\mathrm{BP}$ and $\mathrm{HP}$ were the same between WPC80 and SPC80. Increased volatile sulfur compounds along with higher elemental sulfur in

Table 8. Mean $(\mathrm{n}=3)$ foam stability and yield stress of foams from $80 \%$ serum protein concentrate (SPC80) with and without annatto color added to the milk followed by no bleaching, bleaching with benzoyl peroxide (BP, $50 \mathrm{mg} / \mathrm{kg}$ ), or bleaching with hydrogen peroxide (HP, $500 \mathrm{mg} / \mathrm{kg}$ )

\begin{tabular}{lcccccccc}
\hline & \multicolumn{9}{c}{ Treatment } & & \\
\cline { 2 - 5 } Item & No color & $\begin{array}{c}\text { No color } \\
+\mathrm{BP}\end{array}$ & $\begin{array}{c}\text { No color } \\
+\mathrm{HP}\end{array}$ & Annatto & $\begin{array}{c}\text { Annatto } \\
+\mathrm{BP}\end{array}$ & $\begin{array}{c}\text { Annatto } \\
+\mathrm{HP}\end{array}$ & $\mathrm{R}^{2}$ & $\mathrm{SE}$ \\
\hline Foam stability (min) & $24.9^{\mathrm{c}}$ & $31.8^{\mathrm{a}}$ & $30.2^{\mathrm{a}}$ & $27.5^{\mathrm{b}}$ & $30.1^{\mathrm{a}}$ & $27.5^{\mathrm{b}}$ & 0.89 & 0.74 \\
Yield stress (Pa) & $38.9^{\mathrm{b}}$ & $43.9^{\mathrm{a}}$ & $38.4^{\mathrm{b}}$ & $42.9^{\mathrm{ab}}$ & $38.5^{\mathrm{b}}$ & $29.8^{\mathrm{c}}$ & 0.84 & 1.60 \\
\hline
\end{tabular}

${ }^{\mathrm{a}-\mathrm{c}}$ Means in the same row not sharing a common superscript are different $(P<0.05)$. 
HP-treated SPC80 in the current study suggest sulfur amino acid catabolism. Further research is needed to determine amino acid profiles of HP- and BP-treated proteins to confirm these effects. The SPC 80 bleached with $\mathrm{BP}$ were lower in sweet aromatic and higher in cardboard flavors compared with unbleached SPC80 $(P<0.05)$ because of increased lipid oxidation. The bleaching mechanisms of $\mathrm{HP}$ and $\mathrm{BP}$ are different, so it is expected that products and off-flavors from these pathways would also be distinct, as previously noted by Jervis et al. (2012). Hydrogen peroxide bleaching may also result in Fenton reactions (Jervis et al., 2012). The decreased iron observed in HP-bleached SPC80 could be caused by iron-catalyzed HP decomposition, thus allowing for more radical peroxidation and increased concentrations of hydroxyl radicals that can lead to increased lipid oxidation. This mechanism was previously suggested by Jervis et al. (2012) for HP bleaching of WPC80.

\section{Functionality}

The WPC80 with similar manufacture and treatment to SPC80 manufactured in this study did not produce any foams (Jervis et al., 2012). However, all SPC80 in the current study foamed, likely because of the lower fat content compared with WPC80 (0.52 vs. $4.67 \%$ on a dry basis, respectively). Properties of foaming, such as overrun, foam stability, and yield stress, depend on the ability of proteins to unfold and orient at the air-water interface (Schmidt, 1984). Foam stability in SPC80 was significantly affected by bleaching. The foams of SPC80 bleach treatments were more stable than those of unbleached SPC80. Previous studies have indicated that foaming is enhanced by oxidizing agents, such as BP and HP, suggesting a potential role of sulfhydryldisulfide-mediated protein conformational reactions in the foaming process (Schmidt, 1984). This suggests that BP and HP cause protein denaturation and that these effects on foaming previously were not detected in WPC80 because of their high fat content.

The solubility of SPC80 also varied depending on bleach treatment and $\mathrm{pH}$. Samples without bleach were highly insoluble at $\mathrm{pH} 3$ and 4 . Benzoyl peroxidebleached samples were highly insoluble at $\mathrm{pH} 4$ and 5 , whereas HP-bleached samples were highly insoluble only at $\mathrm{pH} 5$. No differences in solubility at $\mathrm{pH} 6$ or 7 were detected among samples. No differences among samples at various $\mathrm{pH}$ values were observed in WPC80 with different bleach treatments (Jervis et al., 2012). The elevated fat content might have obscured the significant differences among WPC80 and, without this obscuring factor, differences in solubility due to bleaching might have been more discernible in SPC80 than in WPC80.
As protein denatures, it is more likely to precipitate, thus leading to decreased solubility. Similar trends in heat stability among SPC80 were also observed among WPC80 (Jervis et al., 2012). The HP-bleached SPC80 did not gel after 10 min of heating, whereas both the BP-bleached and the unbleached samples did form gels. This same result was seen in WPC80 (Jervis et al., 2012). Jervis et al. (2012) hypothesized that bleaching with HP damaged proteins in WPC80 differently than did bleaching with $\mathrm{BP}$ or not bleaching. Hydrogen peroxide may attack other conjugated double bonds, leading to increased free radicals, which would increase protein degradation or amino acid damage. However, BP appears to be more specific, attacking primarily norbixin (Jervis et al., 2012). These differences in oxidation and oxidation products may also be due to differences in solubility of the bleaching agents themselves. Oxidation of proteins leads to cleavage of peptide bonds, producing free amino acids and amino acid residues that are highly susceptible to oxidation (Stadtman and Levine, 2003). Oxidation of free amino acids may also be due to the Fenton reaction system (Stadtman and Levine, 2003). Consistent with WPC80 results, HP-bleached SPC80 contained decreased amounts of elemental iron, suggesting that the Fenton reaction had occurred (Jervis et al., 2012).

Compared with BP-bleached SPC80, HP-bleached SPC80 may contain smaller fractions of protein, which are unable to align quickly and gel within $10 \mathrm{~min}$ of heating. Smaller fragments would take more time to aggregate and align to form a gel than intact proteins and have been shown to increase the denaturation temperature of $\beta$-LG (Barbeau et al., 1996). Jervis et al. (2012) noted that HP appeared to improve the heat stability temperature of the whey protein, which may enhance functionality. However, it was unclear if the amino acids were damaged, which would then affect the nutritional value. Future work comparing HP and BP bleaching should include amino acid compositional analysis compared with unbleached controls.

\section{CONCLUSIONS}

Without the confounding effect of the cheese-making procedure, the contribution of bleaching on protein flavor and functionality was confirmed and clarified. Functionality differences were more prevalent in bleached SPC80 compared with previous studies conducted with WPC80, suggesting that bleaching affects functional properties as well as flavor. Benzoyl peroxide exhibited higher bleaching efficiency and created fewer off-flavors in SPC80 than did HP, which is consistent with previous studies with WPC80. Hydrogen peroxide may improve the heat stability of rehydrated SPC80, 
potentially enhancing functionality when used as an ingredient in heat-treated products. Understanding more about how each step contributes to the overall flavor, without confounding effects, is critical to producing consistent, flavorless dairy protein ingredients that can be used in a variety of applications without influencing consumer acceptability. These results confirm that bleaching affects flavor and functionality of WPC and SPC80 and further suggests the need for alternative bleaching agents.

\section{ACKNOWLEDGMENTS}

The authors thank the New York State Milk Promotion Board (Albany, NY), the Dairy Research Institute (Rosemont, IL) and the Northeast Dairy Foods Research Center (Ithaca, NY) for funding. We are grateful for the technical assistance of Irma Amelia, Steve Beckman, Tom Burke, Maureen Chapman, Chassidy Coon, Aneela Hameed, Jessica Mallozzi, and Mark Newbold from the Department of Food Science at Cornell University (Ithaca, NY), the staff of the Cornell Dairy Plant, and Allen Foegeding and Paige Luck from the Department of Food Bioprocessing and Nutrition Sciences at North Carolina State University (Raleigh) for developing the solubility and heat stability methods. The use of trade names does not imply endorsement nor lack of endorsement of those not mentioned.

\section{REFERENCES}

Adams, M., J. Zulewska, and D. M. Barbano. Effect of annatto addition and bleaching on ultrafiltration flux during production of $80 \%$ whey protein concentrate and $80 \%$ serum protein concentrate. J. Dairy Sci. Accepted. http://dx.doi.org/10.3168/jds.2012-6009.

AOAC International. 2000. Official Methods of Analysis. 17th ed. AOAC, Gaithersburg, MD.

Barbeau, J., S. F. Gauthier, and Y. Pouliot. 1996. Thermal stabilization of $\beta$-lactoglobulin by whey peptide fractions. J. Agric. Food Chem. 44:3939-3945.

Campbell, R. E., R. E. Miracle, and M. A. Drake. 2011a. The impact of starter culture and annatto on the flavor and functionality of whey protein concentrate. J. Dairy Sci. 94:1185-1193.

Campbell, R. E., R. E. Miracle, P. D. Gerard, and M. A. Drake. 2011b. Effects of starter culture and storage on the flavor of liquid whey. J. Food Sci. 76:S354-S361.

Croissant, A. E., E. J. Kang, R. E. Campbell, E. Bastian, and M. A. Drake. 2009. The effect of bleaching agent on the flavor of liquid whey and whey protein concentrate. J. Dairy Sci. 92:5917-5927.

Davis, J. P., and E. A. Foegeding. 2007. Comparisons of the foaming and interfacial properties of whey protein isolate and egg white proteins colloids and surfaces. Colloids Surf. B Biointerfaces $54: 200-210$.

Dickinson, E. 1999. Adsorbed protein layers at fluid interfaces: Interactions, structure and surface rheology. Colloid Surf. B Biointerfaces 15:161-176.

Drake, M. A. 2006. Flavor and flavor carry-through of whey proteins in beverages. Pages 292-300 in The Wonders of Whey... Catch the Power. Proc. 4th Int. Whey Conference. American Dairy Products Institute, Elmhurst, IL.
Drake, M. A., and G. V. Civille. 2003. Flavor lexicons. Compr. Rev. Food Sci. Food Safety 2:33-40.

Drake, M. A., R. E. Miracle, and J. M. Wright. 2009. Sensory properties of dairy proteins. Pages 429-448 in Milk Proteins: From Expression to Food. A. Thompson, M. Boland, and H. Singh, ed. Elsevier, Amsterdam, the Netherlands.

Evans, J. P., J. Zulewska, M. Newbold, M. A. Drake, and D. M. Barbano. 2009. Comparison of composition, sensory and volatile components of thirty four percent whey protein and serum protein concentrates. J. Dairy Sci. 92:4773-4791.

Evans, J. P.. J. Zulewska, M. Newbold, M. A. Drake, and D. M. Barbano. 2010. Comparison of composition and sensory properties of $80 \%$ whey protein and milk serum protein concentrates. J. Dairy Sci. 93:1824-1843.

Frankel, E. N. 2005. Chapter 11: Foods. Pages 299-350 in Lipid Oxidation. 2nd ed. The Oily Press, an imprint of P. J. Barnes and Associates, Bridgewater, UK.

Heino, A. T., J. O. Uusi-Rauva, P. R. Rantamäki, and O. Tossavainen. 2007. Functional properties of native and cheese whey protein concentrate powders. Int. J. Dairy Technol. 60:277-285.

Jervis, S., R. E. Campbell, K. L. Wojciehowski, M. A. Drake, and D. M. Barbano. 2012. Impact of bleaching whey on sensory and functional properties of $80 \%$ whey protein concentrate. J. Dairy Sci. 95:2848-2862.

Kang, E. J., R. E. Campbell, E. Bastian, and M. A. Drake. 2010 Invited review: Annatto and bleaching in dairy foods. J. Dairy Sci. 93:3891-3901.

Liaw, I., H. Eshpari, P. S. Tong, and M. A. Drake. 2010. The impact of antioxidant addition on flavor of Cheddar and Mozzarella whey and Cheddar whey protein concentrate. J. Food Sci. 75:C559C569.

Liaw, I. W., R. E. Miracle, S. M. Jervis, M. A. D. Listiyani, and M. A. Drake. 2011. Comparison of the flavor chemistry and flavor stability of mozzarella and Cheddar wheys. J. Food Sci. 76:C1188C1194.

Listiyani, M. A. D., R. E. Campbell, R. E. Miracle, D. M. Barbano, P. D. Gerard, and M. A. Drake. 2012. Impact of fat separation, temperature, and bleaching agent on bleaching of liquid Cheddar whey. J. Dairy Sci. 95:36-49.

Listiyani, M. A. D., R. E. Campbell, R. E. Miracle, L. O. Dean, and M. A. Drake. 2011. Influence of bleaching on flavor of $34 \%$ whey protein concentrate and residual benzoic acid concentration in dried whey proteins. J. Dairy Sci. 94:4347-4359.

Lloyd, M. A., M. A. Drake, and P. D. Gerard. 2009. Flavor variability and flavor stability of U.S.-produced whole milk powder. J. Food Sci. 74:S334-S343.

Luck, P. J., N. Bray, and E. A. Foegeding. 2001. Factors determining yield stress and overrun of whey protein foams. J. Food Sci. 67:1677-1681.

Marcelo, P. A., and S. H. Rizvi. 2007. Physicochemical properties of liquid virgin whey protein isolate. Int. Dairy J. 18:236-246.

Meilgaard, M. M., G. V. Civille, and B. T. Carr. 1999. The Spectrum descriptive analysis method. Pages 189-254 in Sensory Evaluation Techniques. 4th ed. CRC Press, Boca Raton, FL.

Mercadante, A. Z. 2008. Analysis of carotenoids. Pages 447-478 (Chapter 6) in Food Colorants: Chemical and Functional Properties. C. Socaciu, ed. CRC Press, Boca Raton, FL.

Nelson, B. K., and D. M. Barbano. 2005a. A microfiltration process to maximize removal of serum proteins from skim milk before cheese making. J. Dairy Sci. 88:1891-1900.

Nelson, B. K., and D. M. Barbano. 2005b. Yield and aging of cheddar cheese manufactured from milks with differed milk serum protein contents. J. Dairy Sci. 88:4183-4194.

Phillips, L. G., J. B. German, T. E. Oneill, E. A. Foegeding, V. R. Harwalkar, A. Kilara, B. A. Lewis, M. E. Mangino, C. V. Morr, J. M. Regenstein, D. M. Smith, and J. E. Kinsella. 1990. Standardized procedure for measuring foaming properties of three proteins, a collaborative study. J. Food Sci. 55:1441-1444.

Schmidt, R. H. 1984. Effect of processing on whey protein functionality. J. Dairy Sci. 67:2723-2733. 
Stadtman, E. R., and R. L. Levine. 2003. Free radical-mediated oxidation of free amino acids and amino acid residues in proteins. Amino Acids 25:207-218.

Van den Dool, H., and P. Kratz. 1963. A generalization of the retention index system including linear programmed gas liquid partition chromatography. J. Chromatogr. A 11:463-471.

Whitson, M. E., R. E. Miracle, E. Bastian, and M. A. Drake. 2011. Effect of liquid retentate storage on flavor of spray dried whey protein concentrate and isolate. J. Dairy Sci. 94:3747-3760.

Whitson, M. E., R. E. Miracle, and M. A. Drake. 2010. Sensory characterization of chemical components responsible for cardboard flavor in whey protein. J. Sens. Stud. 25:616-636.
Wilde, P. J. 2000. Interfaces: Their role in foam and emulsion behavior. Curr. Opin. Colloid Interface Sci. 5:176-181.

Wright, B. J., S. E. Zevchak, J. M. Wright, and M. A. Drake. 2009. The impact of agglomeration and storage on flavor and flavor stability of whey protein concentrate 80 and whey protein isolate. J. Food Sci. 74:S17-S29

Zulewska, J., M. Newbold, and D. M. Barbano. 2009. Efficiency of serum protein removal from skim milk with ceramic and polymeric membranes at $50^{\circ} \mathrm{C}$. J. Dairy Sci. 92:1361-1377. 